\title{
Design and Thermal Analysis for Irradiation of Absorber Material Specimens in the High Flux lsotope Reactor
}

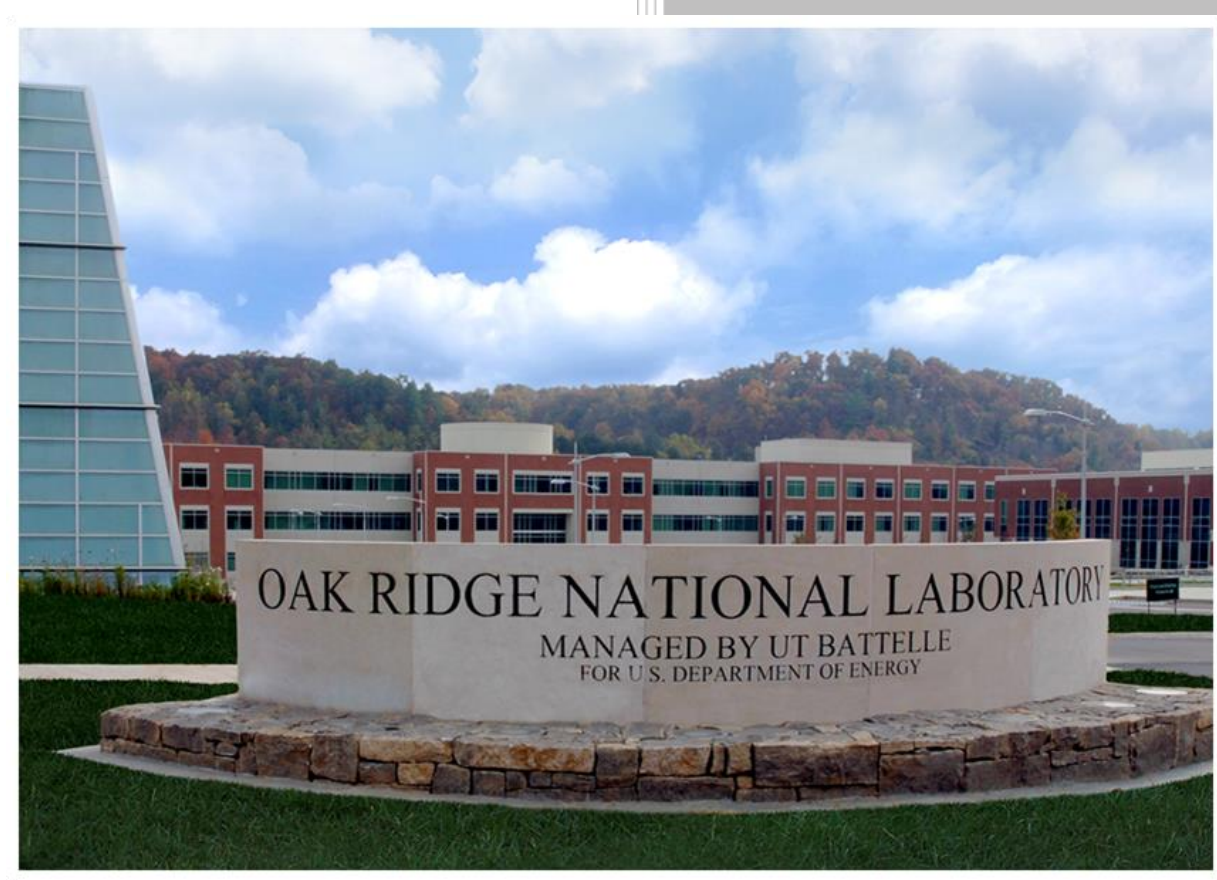

\section{Approved for public release. Distribution is unlimited.}

Nesrin Cetiner Christian M. Petrie Joseph R. Burns Annabelle G. Le Coq Kory D. Linton Jacqueline Stevens

November 2018 


\section{DOCUMENT AVAILABILITY}

Reports produced after January 1, 1996, are generally available free via US Department of Energy (DOE) SciTech Connect.

Website http://www.osti.gov/scitech/

Reports produced before January 1, 1996, may be purchased by members of the public from the following source:

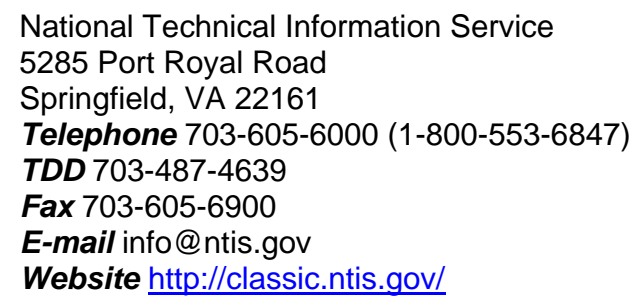

Reports are available to DOE employees, DOE contractors, Energy Technology Data Exchange representatives, and International Nuclear Information System representatives from the following source:

Office of Scientific and Technical Information

PO Box 62

Oak Ridge, TN 37831

Telephone 865-576-8401

Fax 865-576-5728

E-mail reports@osti.gov

Website http://www.osti.gov/contact.html

This report was prepared as an account of work sponsored by an agency of the United States Government. Neither the United States Government nor any agency thereof, nor any of their employees, makes any warranty, express or implied, or assumes any legal liability or responsibility for the accuracy, completeness, or usefulness of any information, apparatus, product, or process disclosed, or represents that its use would not infringe privately owned rights. Reference herein to any specific commercial product, process, or service by trade name, trademark, manufacturer, or otherwise, does not necessarily constitute or imply its endorsement, recommendation, or favoring by the United States Government or any agency thereof. The views and opinions of authors expressed herein do not necessarily state or reflect those of the United States Government or any agency thereof. 
Reactor and Nuclear Systems Division

\title{
Design and Thermal Analysis for Irradiation of Absorber Material Specimens in the High
} Flux Isotope Reactor

\author{
Nesrin Cetiner \\ Christian M. Petrie \\ Joseph R. Burns \\ Annabelle G. Le Coq \\ Kory D. Linton \\ Jacqueline Stevens
}

Date Published: November 30, 2018

\section{NSUF Work Package \#: UF-19OR021009 \\ Work Package Manager: Kory Linton \\ Milestone \#: M3UF-19OR0210092}

\author{
Prepared by \\ OAK RIDGE NATIONAL LABORATORY \\ Oak Ridge, TN 37831-6283 \\ managed by \\ UT-BATTELLE, LLC \\ for the \\ US DEPARTMENT OF ENERGY \\ under contract DE-AC05-00OR22725
}





\section{CONTENTS}

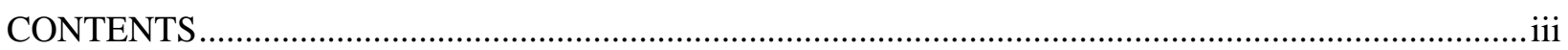

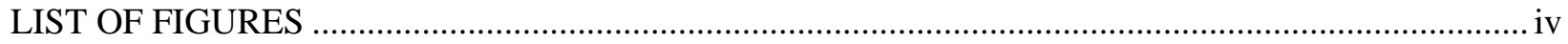

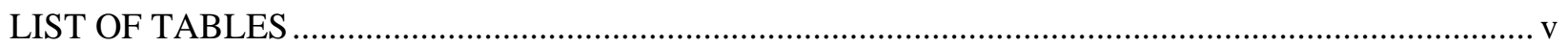

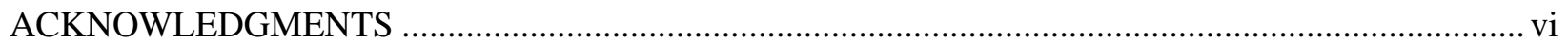

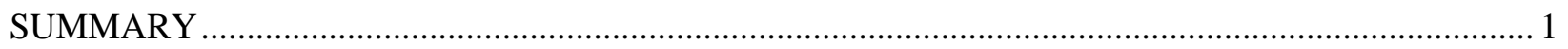

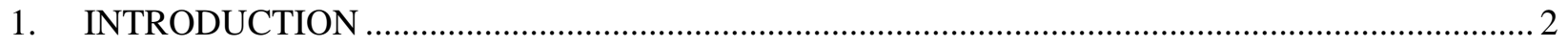

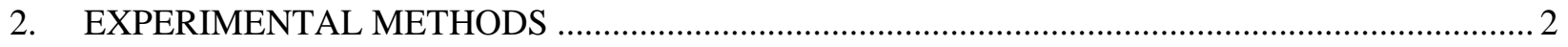

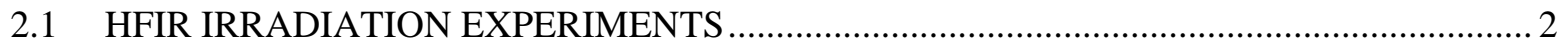

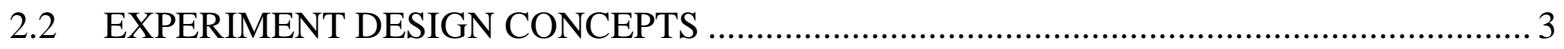

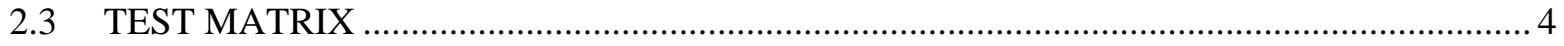

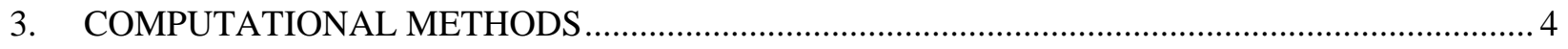

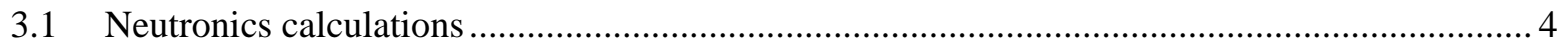

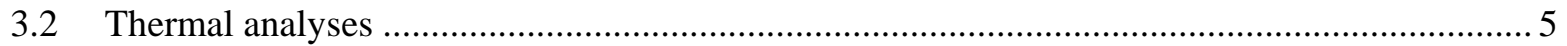

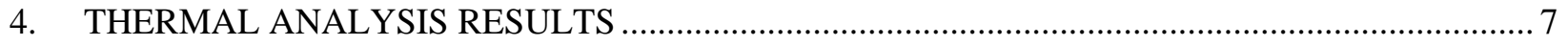

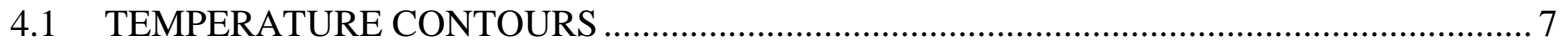

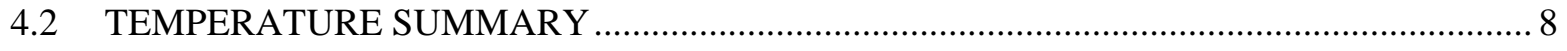

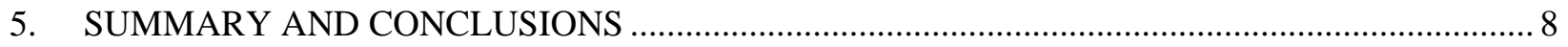

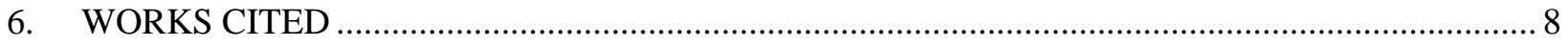

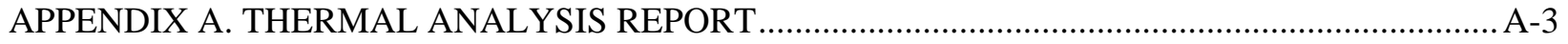




\section{LIST OF FIGURES}

Figure 1. Section view showing irradiation capsule design concept................................................... 3

Figure 2. Radial section view of the irradiation capsule design ......................................................... 4

Figure 3. Predicted temperature contours $\left({ }^{\circ} \mathrm{C}\right)$ showing (a) the internal components, (b) the specimens, and (c) $\mathrm{SiC}$ temperature monitors. 


\section{LIST OF TABLES}

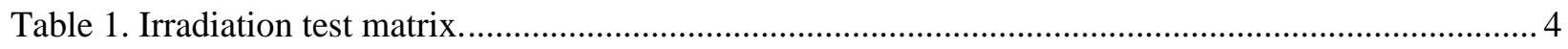

Table 2. Density and heat generation rate results for the absorber materials......................................... 5



Table 4. Thermal boundary conditions for target holder irradiation experiments ...................................... 6

Table 5. Summary of component temperatures, irradiation position, fill gas, and gas gap ...................... 8 


\section{ACKNOWLEDGMENTS}

This research was sponsored by the Nuclear Science User Facilities (NSUF) Program of the US Department of Energy (DOE), Office of Nuclear Energy. Neutron irradiation in the High Flux Isotope Reactor (HFIR) is made possible by the Office of Basic Energy Sciences, US DOE. The report was authored by UT-Battelle under Contract No. DE-AC05-00OR22725 with the US Department of Energy. 


\section{SUMMARY}

This report provides a summary of the irradiation vehicle design and thermal analysis of absorber material specimens planned for irradiation in the flux trap of the High Flux Isotope Reactor (HFIR). Four different absorber materials will be inserted in the same capsule: hafnium carbide without additive (HfC), hafnium carbide with molybdenum silicide additive $\left(\mathrm{HfC}+\mathrm{MoSi}_{2}\right)$, samarium hafnate $\left(\mathrm{Sm}_{2} \mathrm{HfO}_{5}\right)$, and europium hafnate $\left(\mathrm{Eu}_{2} \mathrm{HfO}_{5}\right)$. The capsule design, with target temperatures of $300^{\circ} \mathrm{C}$, will accommodate twelve specimens. Two capsules are planned to be built and irradiated to two different neutron fluence levels. 


\section{INTRODUCTION}

Current commercial nuclear reactors use silver-indium-cadmium (AIC) and boron carbide $\left(\mathrm{B}_{4} \mathrm{C}\right)$ as the primary neutron absorber materials. These absorbers are used to safely shut down the reactor and, for some designs, for controlling reactor power. Recently, there has been increased interest on advanced accident tolerant absorber materials that can survive for extended periods of time during beyond design basis accidents. AIC and $\mathrm{B}_{4} \mathrm{C}$ form low-melting eutectics with the fuel cladding. They can also melt and partially vaporize during accident scenarios.

Alternative absorber materials are being considered that do not form low-melting eutectics with the fuel cladding and are more stable at higher temperatures than those predicted for severe accident conditions. These alternative materials would ideally have equivalent reactivity worth and control rod drop times to minimize the impact on reactor operation.

The purpose of this project is to perform experimental irradiation testing of novel absorber material specimens to understand the effects of irradiation with realistic temperature gradients. The experimental results will quantify irradiation-induced swelling of four absorber materials: hafnium carbide without an additive ( $\mathrm{HfC}$ ), hafnium carbide with molybdenum silicide additive $\left(\mathrm{HfC}+\mathrm{MoSi}_{2}\right.$ ), samarium hafnate $\left(\mathrm{Sm}_{2} \mathrm{HfO}_{5}\right)$, and europium hafnate $\left(\mathrm{Eu}_{2} \mathrm{HfO}_{5}\right)$.

The absorber material specimens will be inserted into the Oak Ridge National Laboratory (ORNL)'s High Flux Isotope Reactor (HFIR) using irradiation capsules, or rabbits, designed to achieve the desired specimen temperatures during irradiation. Swelling will be measured by comparing specimen dimensions before and after irradiation to two different neutron fluence levels. This report summarizes the HFIR irradiation experiments that are being performed to assess performance under irradiation, including the irradiation capsule design concept and thermal analyses.

\section{EXPERIMENTAL METHODS}

\subsection{HFIR IRRADIATION EXPERIMENTS}

The irradiation experiment described in this document will be performed in the flux trap of ORNL's HFIR. The HFIR is a beryllium-reflected, pressurized, light water-cooled and moderated flux trap-type reactor [1]. The core consists of aluminum-clad involute-fuel plates which currently use highly enriched

${ }^{235} \mathrm{U}$ fuel at a power level of $85 \mathrm{MW}$. The reactor core consists of two concentric annular regions, each approximately $61 \mathrm{~cm}$ in height. The flux trap region is located inside the fuel region. The HFIR fuel and all experiment vessels are cooled by the reactor's primary coolant, which is approximately $50-60^{\circ} \mathrm{C}$. A typical HFIR cycle is 25 days. 
The goal of this work is to design experiments to contain the absorber material specimens inside HFIRapproved irradiation vehicles so that they can accumulate the desired dose while being irradiated at the design temperature. Neutron and gamma radiation from the HFIR fuel cause heating of the experiment materials. This heating is accurately determined using neutronics models of the HFIR core. These data are used as inputs to thermal analyses to predict component temperatures during irradiation [2-11]. Experiments in the flux trap are almost always un-instrumented; passive $\mathrm{SiC}$ temperature monitors (TMs) can be used to determine the irradiation temperature post-irradiation [12]. However, detailed neutronic and thermal analyses are required to ensure that capsule design temperatures are achieved. Experiment designs typically use a small insulating gas gap between the holder and the housing. The size of the gap and the choice of the fill gas (typically helium (He), neon ( $\mathrm{Ne})$, argon (Ar), or a mixture) inside the experiment are established so that the heat generated in the experimental components passes through the gas gap and results in the desired temperature drop across the gap. The temperature drop is a function of the heat flux through the gap, the thermal conductivity of the fill gas, and the size of the gas gap.

\subsection{EXPERIMENT DESIGN CONCEPTS}

The irradiation capsule developed in this work is shown in the section views of Figure 1 and Figure 2. The outer containment for the irradiation experiment is the capsule housing, made from aluminum, and is directly cooled on the outer surface by the HFIR's primary coolant. Grafoil insulator disks are placed on both ends inside the housing to reduce axial heat losses. One vanadium alloy holder, placed in the housing, contains 12 plate specimens, 6 passive $\mathrm{SiC}$ temperature monitor (TM) and a $\mathrm{SiC}$ block for a space filler. The nominal dimensions of the specimens are $12 \mathrm{~mm} \times 3.6 \mathrm{~mm} \times 0.50 \mathrm{~mm}$. Retainer springs inserted in between the $\mathrm{SiC}$ TMs keep the specimens pressed against the inner walls of the holder to provide adequate heat transfer. Quartz wool (not shown) is packed to fill the void space at the top of the internal stack inside the holder to keep the specimens from falling out in the case of a spring failure. Support disks provide a platform on which the specimens sit. The titanium centering thimbles are inserted in the ends of the holder and secured by wires to prevent dislodging from the holder. The main function of the thimbles is to keep the holder centered inside the housing and to maintain a constant gas gap between the holder and the housing. Temperature is controlled by varying the size of the gas gap between the holder and the housing. Helium is used as the fill gas.

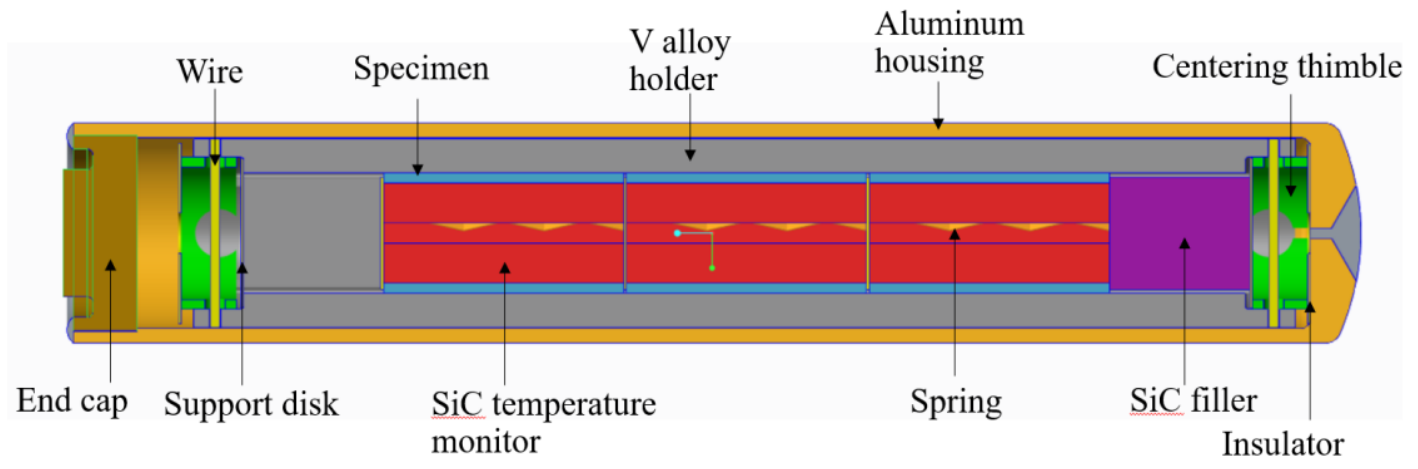

Figure 1. Section view showing irradiation capsule design concept. 


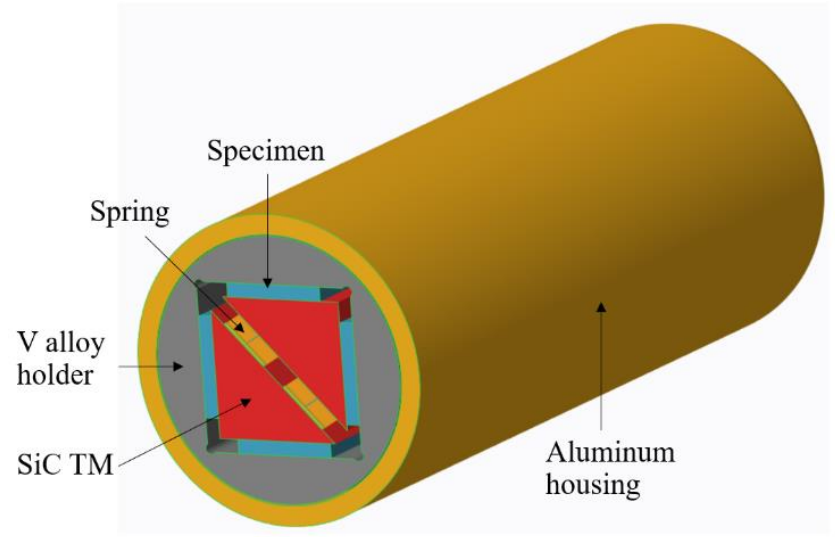

Figure 2. Radial section view of the irradiation capsule design

\subsection{TEST MATRIX}

Table 1 summarizes the different specimens that will be included in the irradiation test matrix. Four absorber materials will be studied: $\mathrm{HfC}, \mathrm{HfC}+\mathrm{MoSi}_{2}, \mathrm{Sm}_{2} \mathrm{HfO}_{5}$, and $\mathrm{Eu}_{2} \mathrm{HfO}_{5}$. A total of 2 capsules, containing 12 specimens each, will be irradiated: 1 capsule will undergo a 6-cycle irradiation (corresponding to an approximated dose of $6 \mathrm{dpa}$ ), and the other a 12-cycle irradiation (corresponding to an approximated dose of $12 \mathrm{dpa}$ ). Both capsules have a nominal design temperature of $300{ }^{\circ} \mathrm{C}$.

Table 1. Irradiation test matrix.

\begin{tabular}{|c|c|c|c|}
\hline Capsule number & $\begin{array}{c}\text { Absorber } \\
\text { material } \\
\text { specimens }\end{array}$ & $\begin{array}{l}\text { Irradiation } \\
\text { dose }\end{array}$ & $\begin{array}{l}\text { Irradiation } \\
\text { temperature }\end{array}$ \\
\hline \multirow{4}{*}{ Capsule \#1 } & $\mathrm{HfC}$ & \multirow{4}{*}{$6 \mathrm{dpa}$} & \multirow{8}{*}{$300^{\circ} \mathrm{C} \pm 25^{\circ} \mathrm{C}$} \\
\hline & $\mathrm{HfC}+\mathrm{MoSi}_{2}$ & & \\
\hline & $\mathrm{Sm}_{2} \mathrm{HfO}_{5}$ & & \\
\hline & $\mathrm{Eu}_{2} \mathrm{HfO}_{5}$ & & \\
\hline \multirow{4}{*}{ Capsule \#2 } & HfC & \multirow{4}{*}{$12 \mathrm{dpa}$} & \\
\hline & $\mathrm{HfC}+\mathrm{MoSi}_{2}$ & & \\
\hline & $\mathrm{Sm}_{2} \mathrm{HfO}_{5}$ & & \\
\hline & $\mathrm{Eu}_{2} \mathrm{HfO}_{5}$ & & \\
\hline
\end{tabular}

\section{COMPUTATIONAL METHODS}

\subsection{NEUTRONICS CALCULATIONS}

Neutronics calculations were performed to determine the heat generation rates for the four absorber materials and the surrounding capsule materials. The standard MCNP model of the HFIR core with cycle 400 experimental loading [13] was modified to include the absorber irradiation assembly described above to assess neutron and photon transport through the materials of interest. For these calculations, the capsules were located in a peripheral target position (PTP) of the HFIR flux trap centered about the axial midplane (PTP position 5). This position results in a conservative estimate of photon flux and therefore provides bounding heating values. 
Heat generation assessment must account for heating from several sources: prompt fission neutrons and photons, delayed photons from fission product decay in the HFIR fuel, and decay heat in the absorbers themselves. Prompt fission neutron and photon heating is assessed directly from heat deposition tallies in the absorbers from an MCNP criticality calculation under beginning of cycle conditions. Delayed photon heating is assessed using a separate fixed source MCNP calculation with a photon source definition representative of the fission product distribution in the HFIR fuel at the end of one day of operation [14]. For activation and decay calculations, the static MCNP analysis must be coupled to the ORIGEN depletion and decay module of the SCALE code system [15]. To this end, during the MCNP criticality calculations, tallies are also defined for the group-wise neutron fluxes and nuclide-specific capture reaction rates in the absorbers; these results are then used to explicitly calculate capture cross sections to be passed to ORIGEN for consistency with MCNP. Given these cross sections and the flux magnitudes and spectra, the ORIGEN calculation is then run to deplete each absorber material over one day of irradiation and assess the resulting decay heat. It is assumed that the portion of decay heat attributed to gamma photon energy is deposited locally. Summing the heating from each of these sources then gives the total heat generation rates reported in Table 2 (as well as the absorber material densities). These results were then used as inputs to the thermal analyses to predict the thermal behavior of the capsule (see next section).

Table 2. Density and heat generation rate results for the absorber materials.

\begin{tabular}{ccc}
\hline Absorber material & Density $\left(\mathbf{g} / \mathbf{c m}^{\mathbf{3}}\right)$ & Heat generation rate $(\mathbf{W} / \mathbf{g})$ \\
\hline $\mathrm{HfC}$ & 11.77 & 95.0 \\
$\mathrm{HfC}+\mathrm{MoSi}_{2}$ & 11.76 & 94.1 \\
$\mathrm{Sm}_{2} \mathrm{HfO}_{5}$ & 7.99 & 115.5 \\
$\mathrm{Eu}_{2} \mathrm{HfO}_{5}$ & 8.17 & 82.4 \\
$\mathrm{~V} 4 \mathrm{Cr} 4 \mathrm{Ti}$ & 6.11 & 46.0 \\
\hline
\end{tabular}

\subsection{THERMAL ANALYSES}

The remainder of this document describes the three-dimensional (3D) thermal analyses that were performed using the ANSYS finite element software package to predict temperature distributions inside the capsule. These analyses use material-dependent heat generation rates (heat per unit mass) determined in previous neutronics analyses. Computer aided design (CAD) models are imported into ANSYS and meshed using 20-node hexagonal and tetrahedral elements with a nominal mesh size of $0.5 \mathrm{~mm}$. Thermal contacts are defined to allow heat to be transferred between multiple bodies. Gas gap heat transfer was assumed to include conduction and radiation only, as there is very little space available for natural convection to occur. The contact conductance of components in contact or separated by the small gas gaps are calculated with user-defined macros [16]. In this way, gas gaps are not directly meshed, which significantly reduces computational time. Gaps for this design are approximately $40 \mu \mathrm{m}$, and the total internal length of the capsule is less than $60 \mathrm{~mm}$. The solver accounts for thermal expansion, though it does not explicitly modify the model geometry. Instead, an effective gap is determined using the initial (cold) dimensions, temperature-dependent thermal expansion data, and the temperatures of the contact and target surface nodes.

The ORNL Nuclear Experiments and Irradiation Testing (NEIT) group maintains a database of design and analysis calculations (DACs) that include temperature-dependent thermophysical material properties used in thermal analyses. Most of the properties are obtained from CINDAS [17], MatWeb [18], and various literature sources. Material properties for this calculation are included in the DACs, as shown in Table 3 and are available upon request. 
Table 3. Experiment materials and material property references

\begin{tabular}{lll}
\hline \multicolumn{1}{c}{ Part } & \multicolumn{1}{c}{ Material } & \multicolumn{1}{c}{ Reference } \\
\hline Holder & Vanadium & DAC-10-05-PROP_V4CR4TI [19] \\
Centering thimbles, springs & Titanium & DAC-11-14-PROP_TI6AL4V [20] \\
Housing, endcap & Aluminum & DAC-10-03-PROP_AL6061 [21] \\
Insulators & Grafoil & DAC-11-16-PROP_GRAFOIL [22] \\
TMs, block & SiC & DAC-10-06-PROP_SIC(IRR) [23] \\
Support disks & Molybdenum & DAC-10-11-PROP_MOLY [24] \\
Fill gas & Helium & DAC-10-02-PROP_HELIUM [25] \\
\hline
\end{tabular}

Convection boundary conditions were applied to the outer surface of the housing. Details of the calculation of the convective heat transfer coefficients and bulk coolant temperatures are summarized in DAC-11-01-RAB03 [26]. These parameters were calculated using turbulent flow correlations and the axial power profile (resulting from neutron and gamma heat generation in the coolant) specific to the peripheral target position in the HFIR flux trap. Temperatures calculated in the thermal analyses are not extremely sensitive to the convection heat transfer coefficient, as the housing surface temperatures are typically only $\sim 10^{\circ} \mathrm{C}$ warmer than the bulk coolant temperature.

The heat generation rates vary as a function of axial position from the midplane of the reactor core. Peak heat generation rates (at the core midplane), parameters for determining the axial profile, and convection parameters are summarized in Table 4. Heat generation rates for aluminum, graphite, molybdenum and $\mathrm{SiC}$ were determined in the HFIR safety basis calculation C-HFIR-2012-035 [27]. The titanium heat generation rate was determined in calculation C-HFIR-2013-003 [28]. Other heat generation rates are calculated for this capsule configuration as described in Section 3.1. These heat generation rates include contributions from prompt neutrons, fission photons and secondary photons produced by the fission neutrons, fission product decay photons, and decay (primarily due to beta emission) of activation sources. Nuclear heating in the HFIR is dominated by photon absorption in the materials used in this experiment.

Table 4. Thermal boundary conditions for target holder irradiation experiments

\begin{tabular}{lc}
\hline Parameter & Value \\
\hline Heat transfer coefficient & $48.4 \mathrm{~kW} \mathrm{~m}^{-2} \mathrm{~K}^{-1}$ \\
Bulk coolant temperature & $54^{\circ} \mathrm{C}$ \\
Peak heat generation rate for aluminum & $32.1 \mathrm{~W} / \mathrm{g}$ \\
Peak heat generation rate for grafoil & $33.8 \mathrm{~W} / \mathrm{g}$ \\
Peak heat generation rate for titanium & $35.6 \mathrm{~W} / \mathrm{g}$ \\
Peak heat generation rate for molybdenum & $42.9 \mathrm{~W} / \mathrm{g}$ \\
Peak heat generation rate for SiC & $34.9 \mathrm{~W} / \mathrm{g}$ \\
Correlating parameter $(\sigma)$ & $30.07 \mathrm{~cm}$ \\
\hline
\end{tabular}

The local heat generation rate is estimated using the following profile:

$$
\mathrm{q}(\text { material, } \mathrm{z})=\mathrm{q}_{\text {peak }}(\text { material }) \cdot \exp \left[-\left(\frac{\mathrm{z}}{\sigma}\right)^{2}\right] \text {, }
$$

where:

$\mathrm{q}=$ local heat generation rate as a function of the material and axial location,

$\mathrm{q}_{\text {peak }}=$ heat generation rate at the HFIR midplane as a function of material,

$\mathrm{z}=$ axial location in the HFIR, where the midplane is at $\mathrm{z}=0$, and

$\sigma=$ correlating parameter 


\section{THERMAL ANALYSIS RESULTS}

\subsection{TEMPERATURE CONTOURS}

Figure 3 shows temperature contours predicted by the thermal analyses. The specimens' average temperatures are within the desired range of $300 \pm 25^{\circ} \mathrm{C}$. However, the temperature gradients within the specimens are quite large. For both $\mathrm{Sm}_{2} \mathrm{HfO}_{5}$ and $\mathrm{Eu}_{2} \mathrm{HfO}_{5}$ specimens, the temperature gradients are as high as $150^{\circ} \mathrm{C}$. The large temperature gradients are due to the low thermal conductivity and the high heat generation rates of the specimens. For the other absorber materials, with higher thermal conductivity, the temperature gradients are much lower (closer to $70^{\circ} \mathrm{C}$ ).

More details are provided in the complete ANSYS reports provided in APPENDIX A. A fill gas with 100\% He was chosen for this design. The holder's $9.44 \mathrm{~mm}$ outer diameter, combined with a nominal housing inner diameter of $9.52 \mathrm{~mm}$, results in a nominal cold (room temperature) holder-to-housing gas gap of $40 \mu \mathrm{m}$. Depending on the as-inspected value of the holder, a suitable housing will be selected so that the as-built holder-to-housing gas gap matches the desired $50 \mu \mathrm{m}$ gap as close as possible.
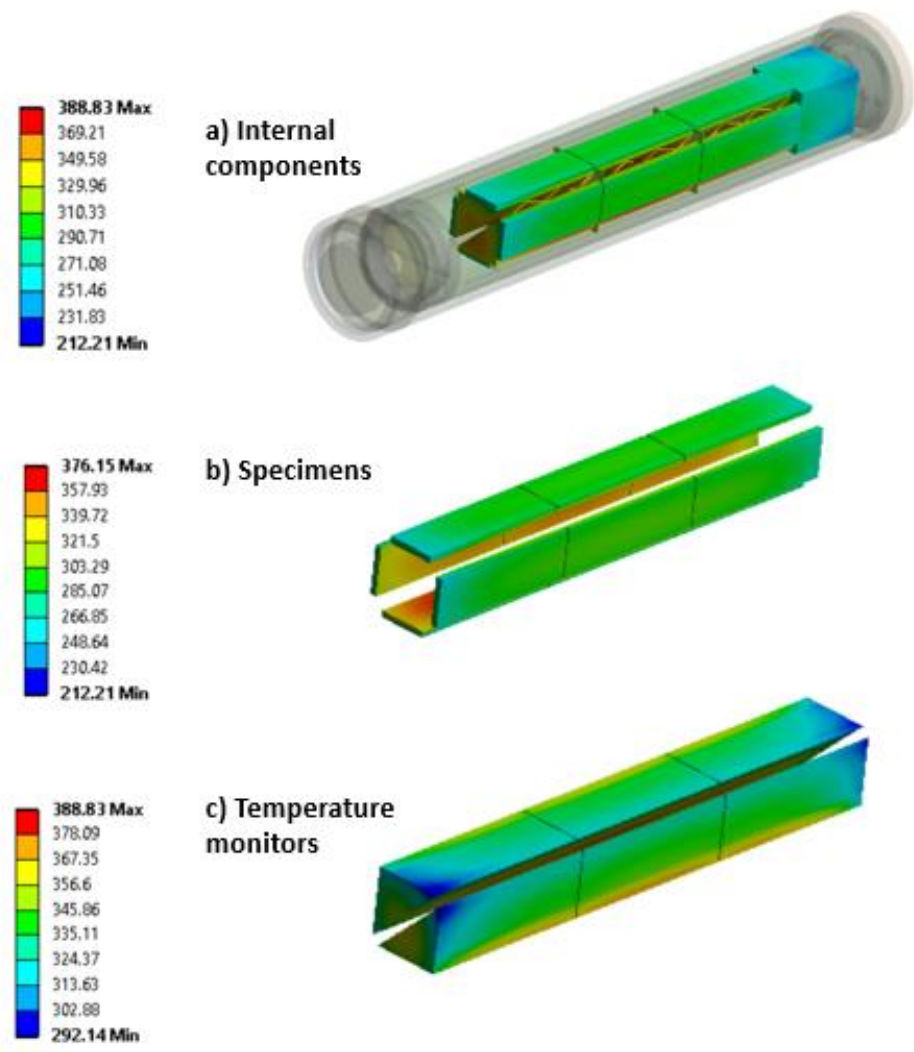

Figure 3. Predicted temperature contours $\left({ }^{\circ} \mathrm{C}\right)$ showing (a) the internal components, $(\mathrm{b})$ the specimens, and (c) SiC temperature monitors. 


\subsection{TEMPERATURE SUMMARY}

Table 5 summarizes average, minimum, and maximum temperatures for all important components, in addition to other design parameters such as the irradiation position, fill gas, and gas gap.

Table 5. Summary of component temperatures, irradiation position, fill gas, and gas gap

\begin{tabular}{|c|c|c|c|c|c|c|}
\hline \multirow{2}{*}{ Position } & \multirow{2}{*}{ Fill gas } & \multirow{2}{*}{ Gas gap } & \multirow{2}{*}{ Part } & \multicolumn{3}{|c|}{ Temperature $\left({ }^{\circ} \mathbf{C}\right)$} \\
\hline & & & & Average & Minimum & Maximum \\
\hline \multirow{7}{*}{ PTP-5 } & \multirow{7}{*}{$\mathrm{He}$} & \multirow{7}{*}{$40 \mu \mathrm{m}$} & HfC specimen & 306 & 258 & 329 \\
\hline & & & $\begin{array}{c}\mathrm{HfC}+\mathrm{MoSi}_{2} \\
\text { specimen }\end{array}$ & 302 & 256 & 323 \\
\hline & & & $\mathrm{Sm}_{2} \mathrm{HfO}_{5}$ specimen & 314 & 222 & 376 \\
\hline & & & $\mathrm{Eu}_{2} \mathrm{HfO}_{5}$ specimen & 296 & 212 & 355 \\
\hline & & & TM & 358 & 292 & 389 \\
\hline & & & Holder & 197 & 135 & 256 \\
\hline & & & Housing & 65 & 57 & 71 \\
\hline
\end{tabular}

\section{SUMMARY AND CONCLUSIONS}

This report summarizes the capsule design and thermal analyses that were performed for irradiation testing of absorber material plate specimens in the HFIR. Four different absorber materials will be inserted in the same capsule: $\mathrm{HfC}, \mathrm{HfC}+\mathrm{MoSi}_{2}, \mathrm{Sm}_{2} \mathrm{HfO}_{5}$, and $\mathrm{Eu}_{2} \mathrm{HfO}_{5}$. The capsule design allows the loading of 12 specimens in a holder, which is centered inside the rabbit housing using centering thimbles. Neutronics calculations were performed to estimate the heat generation rates of the absorber materials. Thermal analyses of this design show that an average design temperature of $300 \pm 25^{\circ} \mathrm{C}$ can be achieved for the absorber material specimens. Ultimately, the data gathered from this experiment will assist in quantifying the irradiation-induced swelling of the different absorber materials, which is needed to demonstrate performance under irradiation.

\section{WORKS CITED}

1. High Flux Isotope Reactor Technical Parameters. Available from: http://neutrons.ornl.gov/hfir/parameters.

2. C.M. Petrie, et al. Small-Scale Fuel Irradiation Testing in the High Flux Isotope Reactor. in Water Reactor Fuel Performance Meeting 2017. 2017. Jeju Island, Korea: Korean Nuclear Society.

3. C.M. Petrie, et al. Miniature Fuel Irradiations in the High Flux Isotope Reactor. in 40th Enlarged Halden Programme Group Meeting. 2017. Lillehammer, Norway: Institutt for energiteknikk.

4. C.M. Petrie, K.G. Field, and K. Linton, Irradiation of Wrought FeCrAl Tubes in the High Flux Isotope Reactor, ORNL/SR-2017/466, Oak Ridge National Laboratory, Oak Ridge, TN, 2017.

5. Christian M. Petrie, et al., Analysis and Experimental Qualification of an Irradiation Capsule Design for Testing Pressurized Water Reactor Fuel Cladding in the High Flux Isotope Reactor, ORNL/TM-2017/67, Oak Ridge National Laboratory, Oak Ridge, TN, 2017. 
6. Christian M. Petrie, et al., Experimental design and analysis for irradiation of SiC/SiC composite tubes under a prototypic high heat flux, Journal of Nuclear Materials, 2017, 491: p. 94-104, DOI: https://doi.org/10.1016/j.jnucmat.2017.04.058.

7. C.M. Petrie and T. Koyanagi, Assembly and Delivery of Rabbit Capsules for Irradiation of Silicon Carbide Cladding Tube Specimens in the High Flux Isotope Reactor, ORNL/TM-2017/433, Oak Ridge National Laboratory, Oak Ridge, TN, 2017.

8. C.M. Petrie, et al., Irradiation of Miniature Fuel Specimens in the High Flux Isotope Reactor, ORNL/SR-2018/844, Oak Ridge National Laboratory, Oak Ridge, TN, 2018.

9. Christian M. Petrie, Kurt R. Smith, and Tyler J. Gerczak, Design and Thermal Analysis for Irradiation of Pyrolytic Carbon/Silicon Carbide Diffusion Couples in the High Flux Isotope Reactor, ORNL/TM-2017/390, Oak Ridge National Lab, Oak Ridge, TN, 2017. https://www.osti.gov/servlets/purl/1399950.

10. Padhraic L. Mulligan, et al., An F82H steel pressurized tube creep capsule for irradiation in HFIR, Nuclear Materials and Energy, 2018, 15: p. 254-260, DOI: https://doi.org/10.1016/j.nme.2018.05.011.

11. Christian M. Petrie, et al., Design and Thermal Analysis for Irradiation of Silicon Carbide Joint Specimens in the High Flux Isotope Reactor, ORNL/TM-2018/940, Oak Ridge National Laboratory, Oak Ridge, TN, 2018. https://www.osti.gov/servlets/purl/1470851.

12. A. Campbell, et al., Method for analyzing passive silicon carbide thermometry with a continuous dilatometer to determine irradiation temperature, Nuclear Instruments and Methods in Physics Research B, 2016, 370: p. 49-58.

13. G. Ilas, et al., Modeling and Simulations for the High Flux Isotope Reactor Cycle 400, ORNL/TM2015/36, 2015.

14. D. Chandler, Activation and Heat Generation Calculations to Support Pu-238 Fully Loaded Target Irradiations in Inner Small VXFs for up to Three Cycles, C-HFIR-2015-014, 2015.

15. Scale: A Comprehensive Modeling and Simulation Suite for Nuclear Safety Analysis and Design, ORNL/TM-2005/39, 2011.

16. J.L. McDuffee. Heat Transfer Through Small Moveable Gas Gaps in a Multi-Body System Using the ANSYS Finite Element Software. in ASME 2013 Heat Transfer Summer Conference. 2013. Minneapolis, MN.

17. LLC CINDAS, Global Benchmark for Critically Evaluated Materials Properties Data. cited 27 July, 2016.

18. MatWeb. Material Property Data. [cited 2016 July 27]; Available from: http://matweb.com/.

19. J. L. McDuffee, Thermophysical Properties for V-4CrTi, DAC-10-05-PROP_V4CR4TI Rev. 1, Oak Ridge National Laboratory, Oak Ridge, TN, 2013.

20. J.L. McDuffee, Thermophysical Properties for Titanium Alloy Ti-6Al4V, DAC-11-14PROP_TI6AL4V, Rev. 1, Oak Ridge National Laboratory, Oak Ridge, TN, 2013.

21. J.L. McDuffee, Thermophysical Properties for AL6061, DAC-10-03-PROP_AL6061, Rev.2,, Oak Ridge National Laboratory, Thermal Hydraulics and Irradiation Engineering Group, Oak Ridge, TN, 2013.

22. J.L. McDuffee, Thermophysical Properties for Flexible Graphite, DAC-11-16-PROP_GRAFOIL, Rev. 0,, Oak Ridge National Laboratory, Oak Ridge, TN, 2013.

23. J.L. McDuffee, Thermophysical Properties for Irradiated SiC, DAC-10-06-PROP_SIC(IRR), Rev. 2, Oak Ridge National Laboratory, Thermal Hydraulics and Irradiation Engineering Group, Oak Ridge, TN, 2013.

24. J.L. McDuffee, Thermophysical Properties for Molybdenum, DAC-10-11-PROP_MOLY, Rev.1, Oak Ridge National Laboratory, Oak Ridge, TN,, 2013.

25. J.L. McDuffee, Thermophysical Properties for Helium, DAC-10-02-PROP_HELIUM, Rev. 0, Oak Ridge National Laboratory, Thermal Hydraulics and Irradiation Engineering Group, Oak Ridge, TN, 2010. 
26. J.L. McDuffee, Heat Transfer Coefficients and Bulk Temperatures for HFIR Rabbit Facilities, DAC-11-01-RAB03, Rev. 0, Oak Ridge National Laboratory, Thermal Hydraulics and Irradiation Engineering Group, Oak Ridge, TN, 2011.

27. J L McDuffee, Heat Generation Rates for Various Rabbit Materials in the Flux Trap of HFIR, CHFIR-2012-035, Rev. 0 Oak Ridge National Laboratory, Oak Ridge, TN, 2012.

28. C. Daily, Heat Generation Rates for Various Titanium and Silicon Compounds in the Flux Trap of HFIR, C-HFIR-2013-003, Rev. 0, Oak Ridge National Laboratory, Oak Ridge, TN, 2013. 
APPENDIX A. THERMAL ANALYSIS REPORT 


$$
\text { A-2 }
$$




\section{APPENDIX A. THERMAL ANALYSIS REPORT}

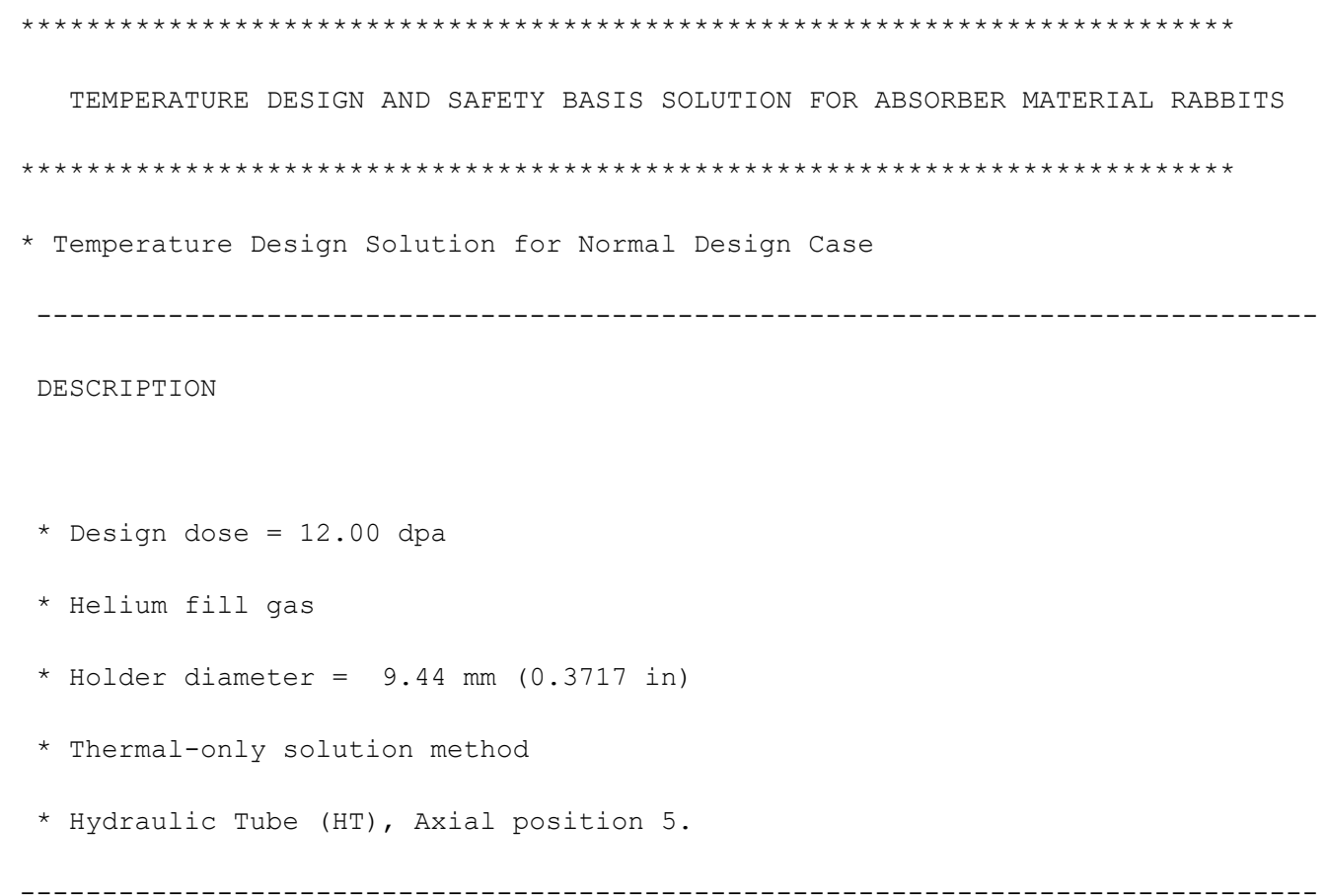

COLD MODEL DIMENSIONS

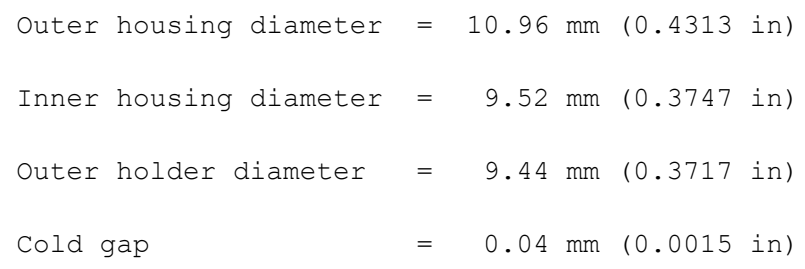

BOUNDARY CONDITIONS

Heat transfer coefficient $=48400 . \mathrm{W} / \mathrm{m}^{2} \cdot{ }^{\circ} \mathrm{C}$

Bulk coolant temperature $=54.0{ }^{\circ} \mathrm{C}$

HEAT GENERATION

Heat Gen. ------ Heat Load ----- 


\begin{tabular}{|c|c|c|c|c|c|}
\hline & & & @Midplane & @Midplane & ¿Location \\
\hline $\mathrm{Pa}$ & $r t$ & Material & $(\mathrm{W} / \mathrm{kg})$ & $(W)$ & $(W)$ \\
\hline 1) & Housing & $\mathrm{AL}-6061$ & 32100 . & 5.2 & 5.1 \\
\hline 3) & Housing & $A L-6061$ & 32100 . & 117.7 & 117.1 \\
\hline 5) & Housing & $\mathrm{AL}-6061$ & 32100 . & 14.6 & 14.6 \\
\hline 7) & EndCap & $\mathrm{AL}-6061$ & 32100 . & 1.7 & 1.6 \\
\hline 9) & EndCap & $\mathrm{AL}-6061$ & 32100 . & 4.1 & 4.0 \\
\hline 11) & EndCap & $\mathrm{AL}-6061$ & 32100 . & 14.1 & 13.8 \\
\hline 13) & Holder & $\mathrm{V}-4 \mathrm{Cr} 4 \mathrm{Ti}$ & 46021 . & 497.4 & 495.4 \\
\hline 15) & Holder & $\mathrm{V}-4 \mathrm{Cr} 4 \mathrm{Ti}$ & 46021 . & 16.6 & 16.3 \\
\hline 17) & Disk_bottom & Moly & 42900 . & 2.3 & 2.3 \\
\hline 18) & EuHafnate. 1 & $\mathrm{HFO} 2$ & 82360 . & 14.5 & 14.5 \\
\hline 19) & TMa. 1 & $\operatorname{SiC}(\operatorname{Irr})$ & 34900 . & 13.6 & 13.6 \\
\hline 20) & $\mathrm{TMb} .1$ & $\operatorname{SiC}(\operatorname{Irr})$ & 34900 . & 13.6 & 13.6 \\
\hline 21) & Springa.1 & $\mathrm{Ti}-6 \mathrm{Al} 4 \mathrm{~V}$ & 35600 . & 0.3 & 0.3 \\
\hline 22) & Spacer.1 & $\operatorname{SiC}(\operatorname{Irr})$ & 34900 . & 0.5 & 0.5 \\
\hline 23) & Disk_up & Moly & 42900 . & 2.3 & 2.3 \\
\hline 24) & Spacer.2 & $\operatorname{SiC}(\operatorname{Irr})$ & 34900 . & 0.5 & 0.5 \\
\hline 25) & Spacer.3 & $\operatorname{SiC}(\operatorname{Irr})$ & 34900 . & 0.5 & 0.5 \\
\hline 26) & Wire_up & Moly & 42900 & 0.8 & 0.8 \\
\hline 27) & Wire_bottom & Moly & 42900 . & 0.8 & 0.8 \\
\hline 28) & Insulator_bottom & GRAFOIL & 33800 . & 0.2 & 0.2 \\
\hline 29) & SmHafnate. 1 & $\mathrm{HFO} 2$ & 115465 . & 19.9 & 19.9 \\
\hline 30) & $\mathrm{HfC} .1$ & $\mathrm{HFO} 2$ & 94965 . & 24.1 & 24.1 \\
\hline 31) & HfCMoSi2. 1 & $\mathrm{HFO} 2$ & 94965 . & 24.1 & 24.1 \\
\hline 32) & Spring_b.1 & $\mathrm{Ti}-6 \mathrm{Al} 4 \mathrm{~V}$ & 35600 . & 0.3 & 0.3 \\
\hline 33) & Insulator_top & GRAFOIL & 33800 . & 0.2 & 0.2 \\
\hline 34) & Thimble_top & $\mathrm{Ti}-6 \mathrm{Al} 4 \mathrm{~V}$ & 35600 . & 5.0 & 4.9 \\
\hline 35) & Thimble_bottom & $\mathrm{Ti}-6 \mathrm{Al} 4 \mathrm{~V}$ & 35600 . & 5.0 & 5.0 \\
\hline 36) & Block & $\operatorname{SiC}(\operatorname{Irr})$ & 34900 . & 26.4 & 26.4 \\
\hline
\end{tabular}




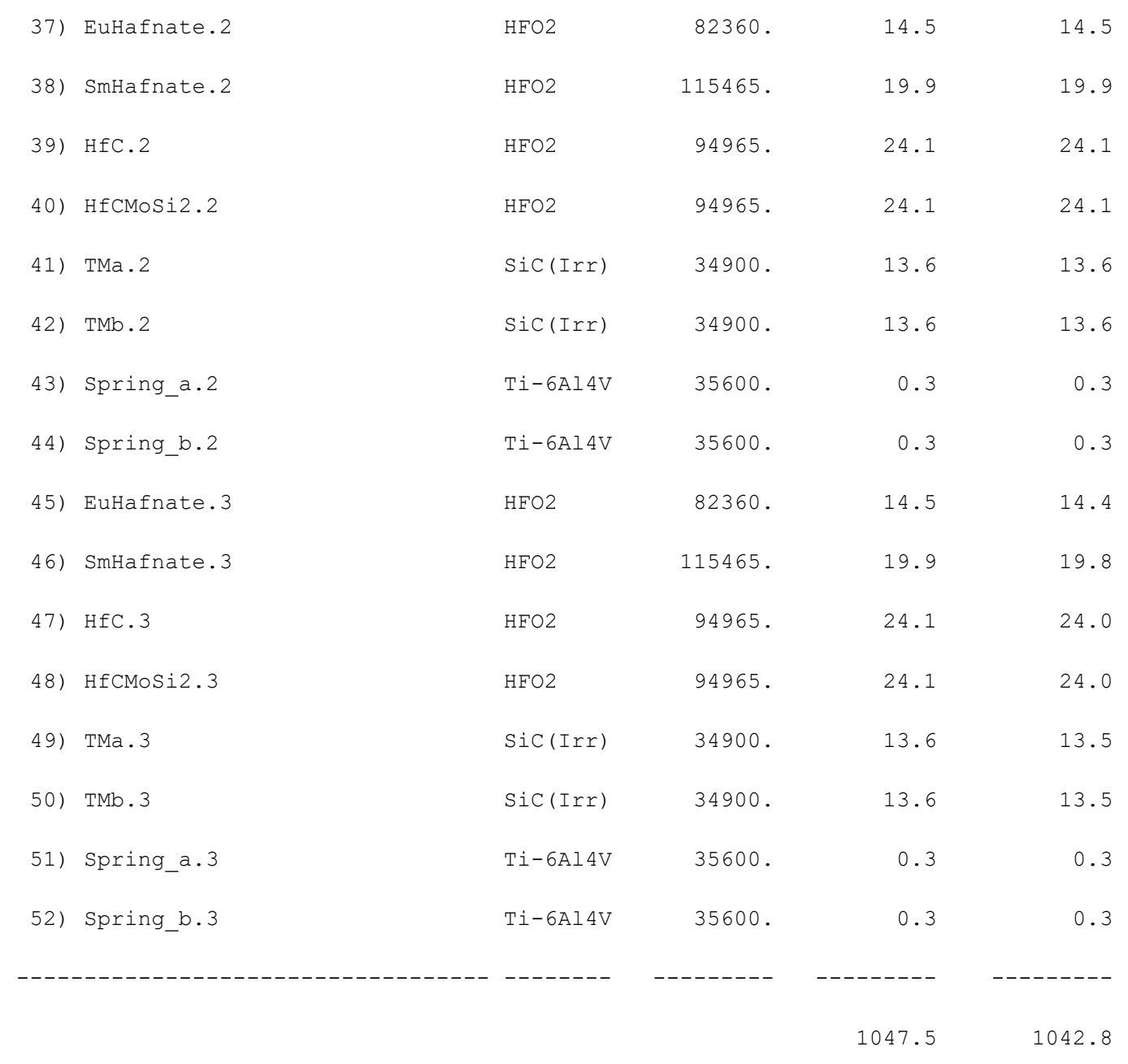

CAPSULE TEMPERATURE SUMMARY

\begin{tabular}{|c|c|c|c|c|c|c|c|}
\hline \multicolumn{2}{|c|}{ Name } & Material & Tavg & Tmin & Tmax & T.025 & T.975 \\
\hline---- & --- & -------- & ----- & ----- & ----- & ----- & --- \\
\hline 1) & Housing & $\mathrm{AL}-6061$ & 58. & 58. & 59. & 58. & 59. \\
\hline 3) & Housing & $\mathrm{AL}-6061$ & 65. & 57. & 71. & 58. & 69. \\
\hline 5) & Housing & $\mathrm{AL}-6061$ & 65. & 61. & 67. & 62. & 67. \\
\hline 7) & EndCap & $A L-6061$ & 88. & 87. & 89. & 88. & 88. \\
\hline 9) & EndCap & $A L-6061$ & 92. & 91. & 93. & 92. & 93. \\
\hline 11) & EndCap & $\mathrm{AL}-6061$ & 90. & 88. & 92. & 88. & 92. \\
\hline 13) & Holder & $\mathrm{V}-4 \operatorname{Cr} 4 \mathrm{Ti}$ & 197. & 135. & 256. & 146. & 242. \\
\hline
\end{tabular}




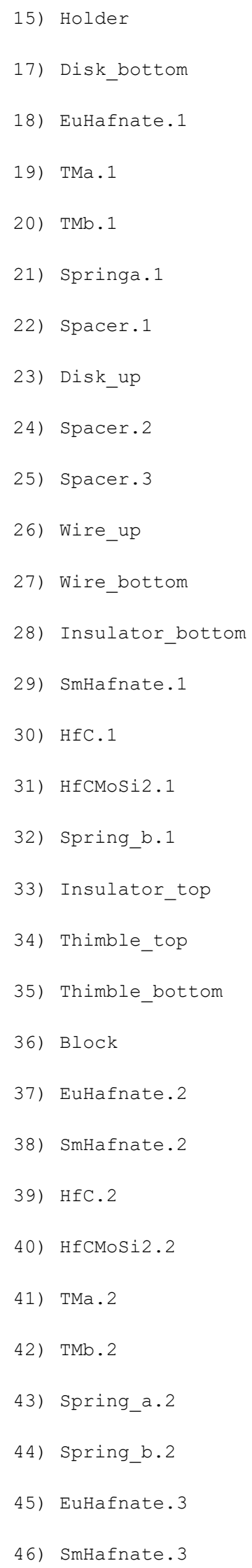




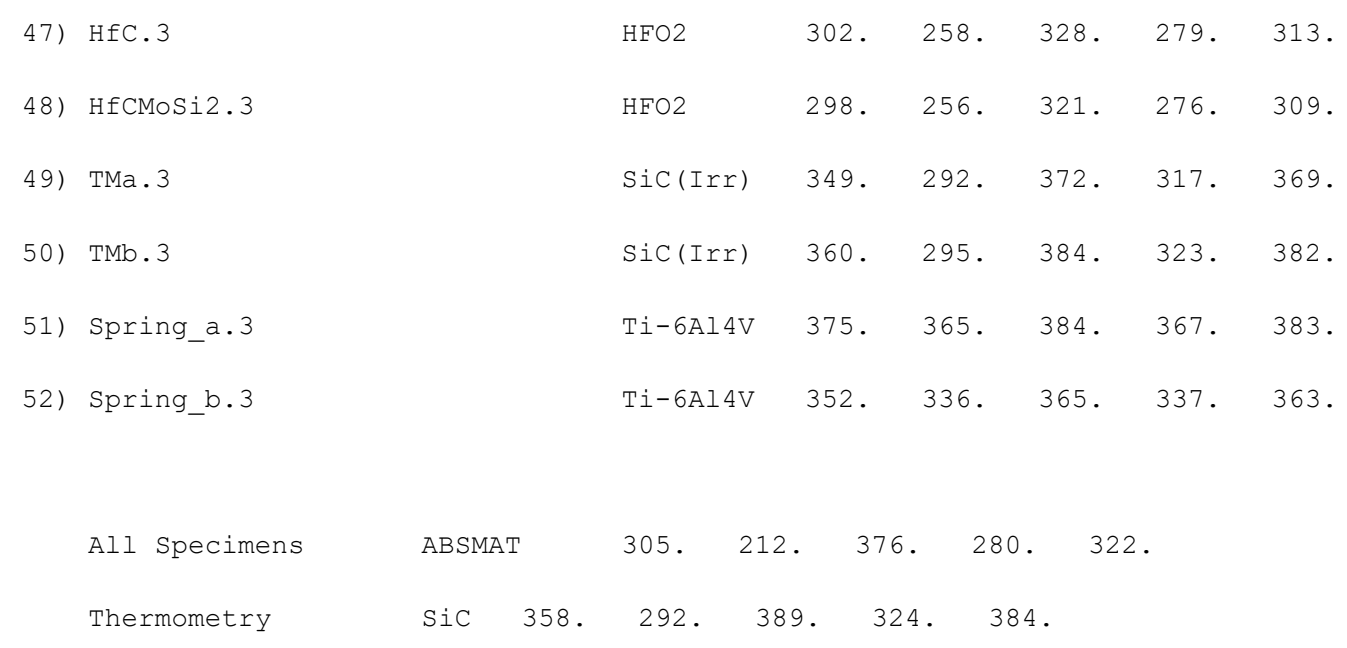

PROPERTY SUMMARY AT THE AVERAGE PART TEMPERATURE

\begin{tabular}{|c|c|c|c|c|c|}
\hline & & & & Thermal & \\
\hline & & & Thermal & Exp. & \\
\hline & & & Cond. & Coeff. & Emis \\
\hline Name & & Material & $\left(\mathrm{W} / \mathrm{m} \cdot{ }^{\circ} \mathrm{C}\right)$ & $\left(\mu \mathrm{m} / \mathrm{m} \cdot{ }^{\circ} \mathrm{C}\right)$ & $(---)$ \\
\hline 1) & Housing & $A L-6061$ & 166.453 & 0.00 & 0.050 \\
\hline 3) & Housing & $\mathrm{AL}-6061$ & 167.301 & 24.21 & 0.050 \\
\hline 5) & Housing & $\mathrm{AL}-6061$ & 167.266 & 0.00 & 0.050 \\
\hline 7) & EndCap & $A L-6061$ & 169.879 & 0.00 & 0.050 \\
\hline 9) & EndCap & $A L-6061$ & 170.336 & 0.00 & 0.050 \\
\hline 11) & EndCap & $A L-6061$ & 170.124 & 0.00 & 0.050 \\
\hline 13) & Holder & $\mathrm{V}-4 \mathrm{Cr} 4 \mathrm{Ti}$ & 31.927 & 9.62 & 0.350 \\
\hline 15) & Holder & $\mathrm{V}-4 \mathrm{Cr} 4 \mathrm{Ti}$ & 31.443 & 0.00 & 0.350 \\
\hline 17) & Disk_bottom & Moly & 128.596 & 0.00 & 0.054 \\
\hline 18) & EuHafnate. 1 & $\mathrm{HFO} 2$ & 1.338 & 0.00 & 0.310 \\
\hline 19) & TMa. 1 & $\operatorname{SiC}(\operatorname{Irr})$ & 6.857 & 3.41 & 0.900 \\
\hline 20) & TMb. 1 & $\operatorname{SiC}(\operatorname{Irr})$ & 7.023 & 3.44 & 0.900 \\
\hline 21) & Springa.1 & $\mathrm{Ti}-6 \mathrm{Al} 4 \mathrm{~V}$ & 14.005 & 0.00 & 0.384 \\
\hline
\end{tabular}




\begin{tabular}{|c|c|c|c|c|c|}
\hline 22) & Spacer.1 & $\operatorname{SiC}(\operatorname{Irr})$ & 6.860 & 3.41 & 0.900 \\
\hline 23) & Disk_up & Moly & 131.662 & 0.00 & 0.046 \\
\hline 24) & Spacer.2 & $\operatorname{SiC}(\operatorname{Irr})$ & 6.843 & 3.41 & 0.900 \\
\hline 25) & Spacer.3 & $\operatorname{SiC}(\operatorname{Irr})$ & 6.449 & 3.34 & 0.900 \\
\hline 26) & Wire_up & Moly & 130.874 & 0.00 & 0.048 \\
\hline 27) & Wire_bottom & Moly & 130.671 & 0.00 & 0.049 \\
\hline 28) & Insulator_bottom & GRAFOIL & 38.000 & 1.00 & 0.500 \\
\hline 29) & SmHafnate. 1 & $\mathrm{HFO} 2$ & 1.404 & 0.00 & 0.310 \\
\hline 30) & $\mathrm{HfC} .1$ & $\mathrm{HFO} 2$ & 10.000 & 0.00 & 0.310 \\
\hline 31) & HfCMoSi2. 1 & $\mathrm{HFO} 2$ & 10.000 & 0.00 & 0.310 \\
\hline 32) & Spring_b.1 & $\mathrm{Ti}-6 \mathrm{Al} 4 \mathrm{~V}$ & 13.525 & 0.00 & 0.376 \\
\hline 33) & Insulator_top & GRAFOIL & 38.000 & 1.00 & 0.500 \\
\hline 34) & Thimble_top & $\mathrm{Ti}-6 \mathrm{Al} 4 \mathrm{~V}$ & 9.652 & 0.00 & 0.320 \\
\hline 35) & Thimble_bottom & $\mathrm{Ti}-6 \mathrm{Al} 4 \mathrm{~V}$ & 9.458 & 0.00 & 0.320 \\
\hline 36) & Block & $\operatorname{SiC}(\operatorname{Ir} r)$ & 5.953 & 3.23 & 0.900 \\
\hline 37) & EuHafnate. 2 & $\mathrm{HFO} 2$ & 1.338 & 0.00 & 0.310 \\
\hline 38) & SmHafnate. 2 & $\mathrm{HFO} 2$ & 1.404 & 0.00 & 0.310 \\
\hline 39) & $\mathrm{HfC} .2$ & $\mathrm{HFO} 2$ & 10.000 & 0.00 & 0.310 \\
\hline 40) & HfCMoSi2. 2 & $\mathrm{HFO} 2$ & 10.000 & 0.00 & 0.310 \\
\hline 41) & TMa. 2 & $\operatorname{SiC}(\operatorname{Irr})$ & 6.984 & 3.43 & 0.900 \\
\hline 42) & $\mathrm{TMB} \cdot 2$ & $\operatorname{SiC}(\operatorname{Irr})$ & 7.166 & 3.46 & 0.900 \\
\hline 43) & Spring_a.2 & $\mathrm{Ti}-6 \mathrm{Al} 4 \mathrm{~V}$ & 14.221 & 0.00 & 0.388 \\
\hline 44) & Spring_b.2 & $\mathrm{Ti}-6 \mathrm{Al} 4 \mathrm{~V}$ & 13.740 & 0.00 & 0.380 \\
\hline 45) & EuHafnate. 3 & $\mathrm{HFO} 2$ & 1.338 & 0.00 & 0.310 \\
\hline 46) & SmHafnate. 3 & $\mathrm{HFO} 2$ & 1.404 & 0.00 & 0.310 \\
\hline 47) & $\mathrm{HfC} .3$ & $\mathrm{HFO} 2$ & 10.000 & 0.00 & 0.310 \\
\hline 48) & HfCMoSi2. 3 & $\mathrm{HFO} 2$ & 10.000 & 0.00 & 0.310 \\
\hline 49) & TMa. 3 & $\operatorname{SiC}(\operatorname{Irr})$ & 6.837 & 3.40 & 0.900 \\
\hline 50) & $\mathrm{TMb} \cdot 3$ & $\operatorname{SiC}(\operatorname{Irr})$ & 7.014 & 3.44 & 0.900 \\
\hline 51) & Spring_a.3 & $\mathrm{Ti}-6 \mathrm{Al} 4 \mathrm{~V}$ & 14.087 & 0.00 & 0.386 \\
\hline 52) & Spring_b.3 & $\mathrm{Ti}-6 \mathrm{Al} 4 \mathrm{~V}$ & 13.585 & 0.00 & 0.377 \\
\hline
\end{tabular}




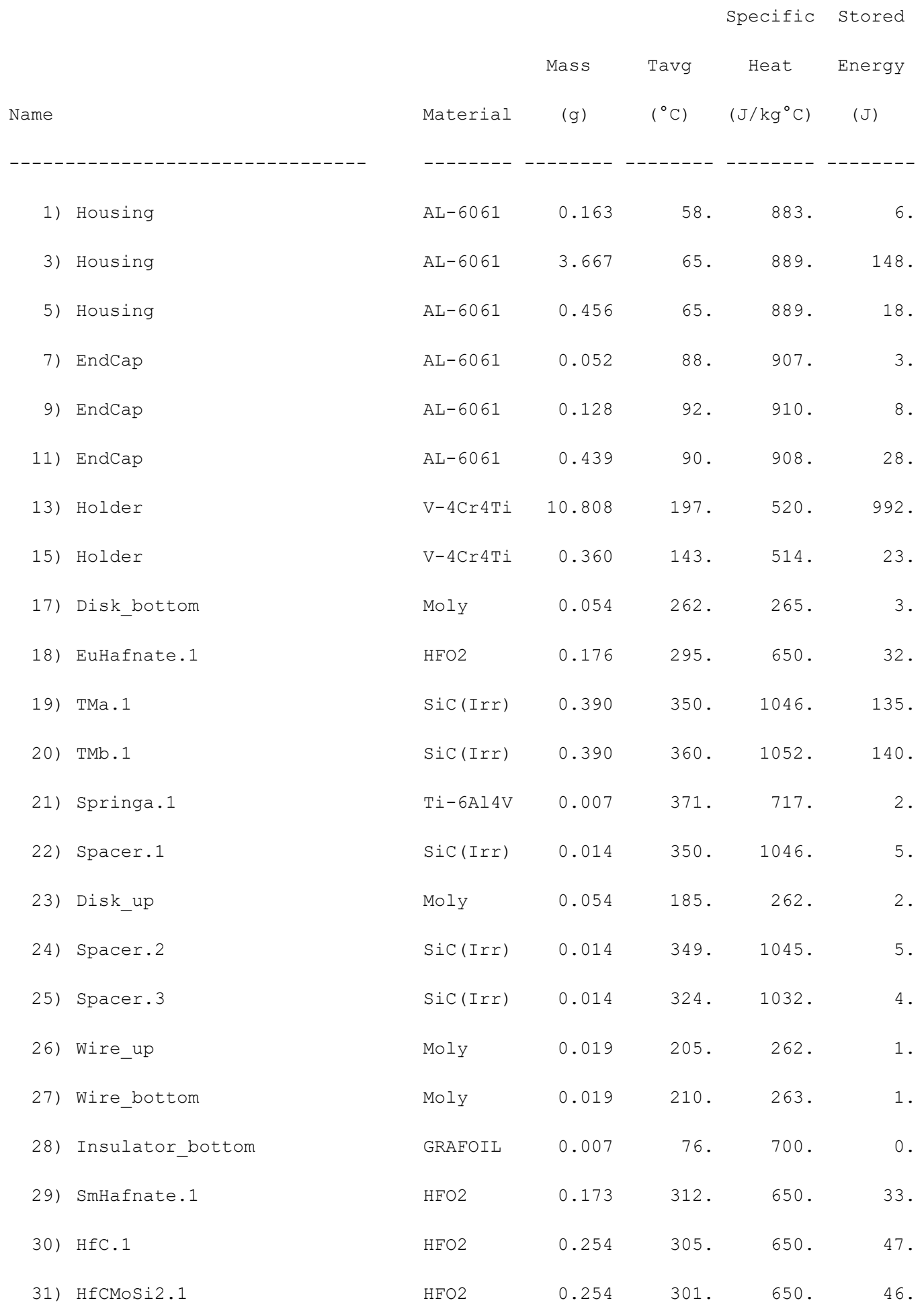




\begin{tabular}{|c|c|c|c|c|c|c|}
\hline 32) & Spring_b.1 & $\mathrm{Ti}-6 \mathrm{Al} 4 \mathrm{~V}$ & 0.007 & 349 & 708. & 2 . \\
\hline 33) & Insulator_top & GRAFOIL & 0.007 & 162. & 700. & 1. \\
\hline 34) & Thimble_top & $\mathrm{Ti}-6 \mathrm{Al} 4 \mathrm{~V}$ & 0.140 & 157. & 633. & 12. \\
\hline 35) & Thimble_bottom & $\mathrm{Ti}-6 \mathrm{Al} 4 \mathrm{~V}$ & 0.140 & 146 & 629. & 11. \\
\hline 36) & Block & $\operatorname{SiC}(\operatorname{Irr})$ & 0.756 & 289 & 1011. & 206. \\
\hline 37) & EuHafnate. 2 & $\mathrm{HFO} 2$ & 0.176 & 301. & 650. & 32 . \\
\hline 38) & SmHafnate. 2 & $\mathrm{HFO} 2$ & 0.173 & 319. & 650. & 34. \\
\hline 39) & $\mathrm{HfC} .2$ & $\mathrm{HFO} 2$ & 0.254 & 312 . & 650. & 48. \\
\hline 40$)$ & HfCMoSi2. 2 & $\mathrm{HFO} 2$ & 0.254 & 308 & 650. & 48 . \\
\hline 41) & TMa.2 & $\operatorname{SiC}(\operatorname{Irr})$ & 0.390 & 358. & 1050 . & 138. \\
\hline 42) & $\mathrm{TMb} .2$ & $\operatorname{SiC}(\operatorname{Irr})$ & 0.390 & 370 & 1057. & 144. \\
\hline 43) & Spring_a.2 & $\mathrm{Ti}-6 \mathrm{Al} 4 \mathrm{~V}$ & 0.007 & 382 . & 721. & 2 . \\
\hline 44) & Spring_b.2 & $\mathrm{Ti}-6 \mathrm{Al} 4 \mathrm{~V}$ & 0.007 & 359. & 712 . & 2 . \\
\hline 45$)$ & EuHafnate. 3 & $\mathrm{HFO} 2$ & 0.176 & 293. & 650. & 31. \\
\hline 46) & SmHafnate. 3 & $\mathrm{HFO} 2$ & 0.173 & 311. & 650. & 33. \\
\hline 47) & $\mathrm{HfC} .3$ & $\mathrm{HFO} 2$ & 0.254 & 302 . & 650. & 47. \\
\hline 48) & HfCMoSi2. 3 & $\mathrm{HFO} 2$ & 0.254 & 298 & 650. & 46. \\
\hline 49) & TMa. 3 & $\operatorname{SiC}(\operatorname{Irr})$ & 0.390 & 349. & 1045 . & 134. \\
\hline 50$)$ & TMb. 3 & $\operatorname{SiC}(\operatorname{Irr})$ & 0.390 & 360 & 1051. & 139. \\
\hline 51) & Spring_a.3 & $\mathrm{Ti}-6 \mathrm{Al} 4 \mathrm{~V}$ & 0.007 & 375 . & 719. & 2. \\
\hline 52$)$ & Spring_b.3 & $\mathrm{Ti}-6 \mathrm{Al} 4 \mathrm{~V}$ & 0.007 & 352 . & 709. & 2 . \\
\hline \multicolumn{7}{|c|}{--------} \\
\hline & & & 22.270 & & & 2795 . \\
\hline
\end{tabular}

CONTACT SUMMARY FOR CONTACT ID 95: Multiple To Housing \{Frictionless\}

$\begin{array}{lc}\text { Contact surface material: } & \text { V-4Cr4Ti } \\ \text { Target surface material: } & \text { AL-6061 } \\ \text { Interstitial gas: } & \text { Helium } \\ \text { Effective surface roughness: } & 2.514 \mu \mathrm{m} \\ \text { Effective asperity slope: } & 0.223 \mathrm{rad}\end{array}$


Effective microhardness: $\quad 1.220 \mathrm{GPa}$

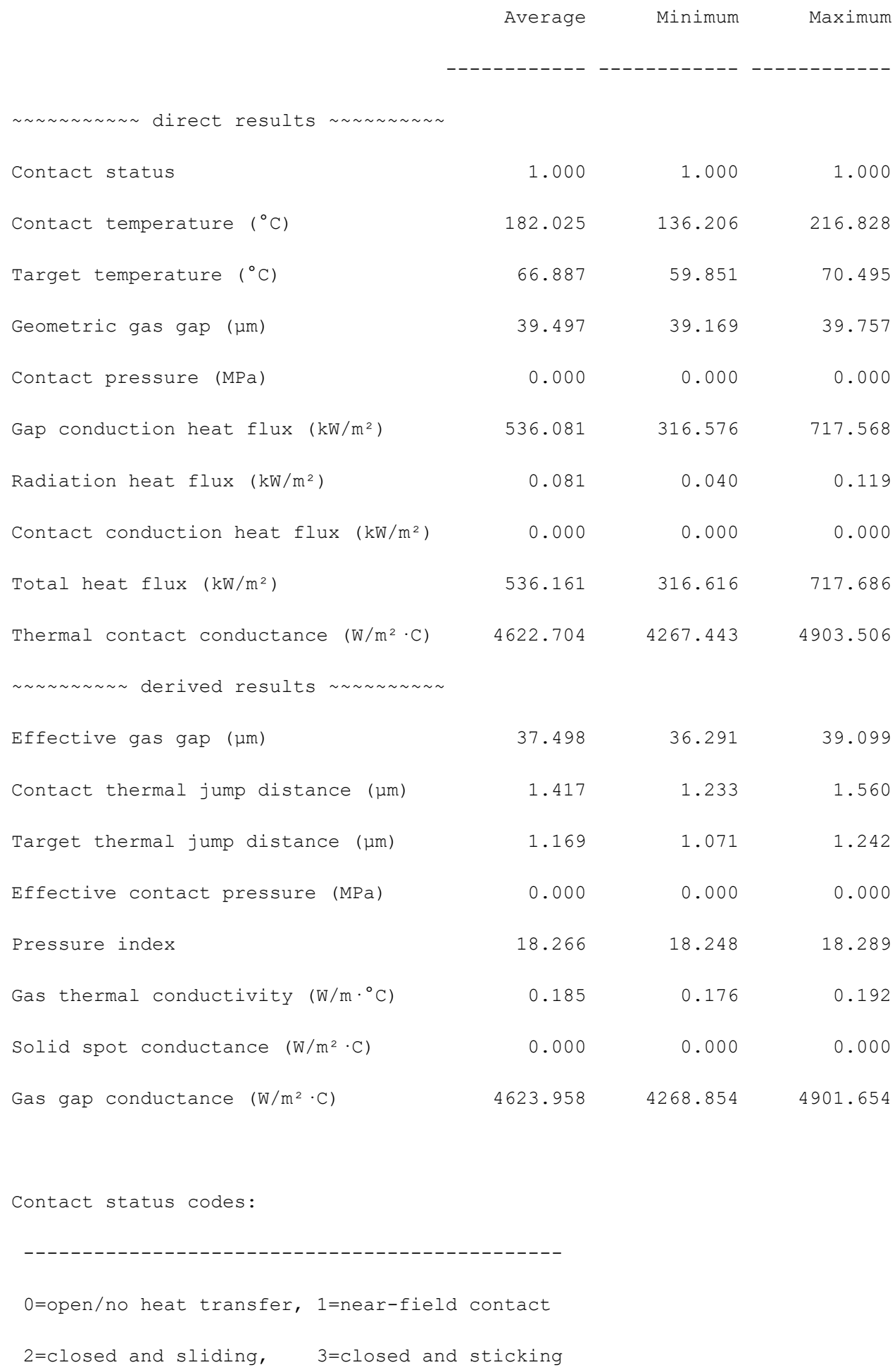

A-11 